\title{
A Obra Científica de Leonardo da Vinci: Controvérsias Na Historiografia da CiênCIA ${ }^{1}$
}

\author{
Amélia de Jesus Oliveira²
}

\begin{abstract}
RESUMO: Os intérpretes dos manuscritos de Leonardo da Vinci partilham dos mesmos sentimentos de espanto e de fascínio quando examinam sua contribuição para a ciência moderna. Podemos, contudo, perceber uma constante tentativa em prol de uma revisão histórica acerca do papel desempenhado por Leonardo. Observando a história dessas revisóes, é possível detectar aspectos significativos das perspectivas históricas e historiográficas dos envolvidos nessa discussão. É o que pretendemos fazer neste trabalho, focando a controvérsia entre Duhem, por um lado, e Sarton, Koyré e Rossi, por outro. Ao fazer isso, buscamos discutir alguns traços que marcam a distinção entre uma historiografia mais antiga e a nova historiografia da ciência, tal como exposta por Thomas Kuhn.
\end{abstract}

PALAVRAS-CHAVE: Leonardo da Vinci. Ciência moderna. Renascença. Continuísmo.

\section{CONSIDERAÇÓES INICIAIS}

Admiração é o sentimento que comumente acompanha os textos interpretativos sobre a contribuição de Leonardo da Vinci para a ciência moderna. Não são poucos os historiadores que enfatizaram o caráter enigmático e perturbador de sua produção, vista invariavelmente como um exemplo privilegiado da capacidade "multifacetada" do homem renascentista, como afirma Burckhardt, em seu livro A cultura do Renascimento na Itália. A imagem de Leonardo aí apresentada parece sintetizar a visão amplamente ratificada posteriormente: "Para sempre [...] os colossais contornos da pessoa de Leonardo só poderão ser divisados à distância” (BURCKHARDT, 1991, p. 118). Podemos observar, entretanto, que essa imagem é um eco das expressôes empregadas por Giorgio Vasari, na terceira parte de sua obra publicada já em 1550, quando analisa a vida de Leonardo da Vinci e afirma:

\footnotetext{
${ }^{1}$ Agradeço a um revisor anônimo pelos comentários proveitosos sobre a primeira versão deste texto. Pesquisa financiada pela Fundação de Amparo à Pesquisa do Estado de São Paulo - FAPESP - Processo 2013/20172-0.

http://dx.doi.org/10.1590/S0101-31732016000200004

2 Pesquisadora de Pós-Doutorado no Departamento de Filosofia do Instituto de Filosofia e Ciências Humanas da Universidade Estadual de Campinas. E-mail: amelijeso@gmail.com
} 
Os maiores dons parecem ser derramados sobre certos seres humanos por uma influência celeste. Muitas vezes naturalmente e, às vezes, de forma sobrenatural, beleza, graça e talento são congregados em um único homem, de tal maneira que, assim favorecido, pode transformar o que quer que seja. Onde quer que ele vá, suas açóes são tão divinas que deixam todos os homens atrás de si, manifestando-se claramente como algo dado por Deus (o que de fato são), e não adquiridas pela arte humana. (VASARI, 1771 , p. 12).

A exaltação e a individualização do trabalho de Leonardo têm sido unânimes entre os historiadores, de um modo geral. Devemos lembrar, entretanto, que as abordagens históricas de Vasari e Burckhardt acerca de Leonardo se distinguem da de outros historiadores quanto ao assunto abordado. Enquanto, por exemplo, Vasari explicita uma fonte de informações sobre "os mais excelentes pintores, escultores e arquitetos", focando dados biográficos e técnicos dos artistas do Renascimento, Burckhardt busca uma caracterização geral da cultura na Renascença.

A concepção burckhardiana da Renascença, em oposição à Idade Média e como período preparatório para a Moderna, segundo Earl Rosenthal (1964, p. 53), “[...] foi prontamente aceita pelos historiadores de seus dias porque, desde o tempo de Vasari, a história da arte tinha sido concebida dessa maneira". É necessário também lembrar que, conforme aponta Ferguson (1950, p. 167), embora muitas das ideias de Burckhardt já houvessem sido postas pelos primeiros humanistas, pelos protestantes e racionalistas, entre outros, seu papel foi muito importante na caracterização da história da Renascença, seja entre aqueles que a ela se opuseram, seja entre os que a defenderam em tom mais moderado, posteriormente.

Ainda assim, a influência desses pensadores é tida como marcante entre os historiadores que lhes seguiram, e isso é bastante claro quando examinamos a história da ciência. Como veremos, a história sobre a obra científica de Leonardo da Vinci tem sofrido revisôes que oscilam entre uma completa recusa da visão defendida por Vasari e Burckhardt e uma reavaliação dessa visão, que mantém algumas de suas características em diferentes matizes. De qualquer modo, em qualquer abordagem, Leonardo invariavelmente tem sido retratado com uma renovada admiração. 


\section{Pierre Duhem e os estudos sobre Leonardo da Vinci}

Duhem (1984, v. I, p. IV-V) declarou que a tarefa de reconstruir a história da evolução da ciência nem sempre é fácil. Os cientistas - ele afirma - não relatam seus passos; não fornecem esboços de seus avanços. $\mathrm{O}$ acesso à suas descobertas é dado quando elas se encontram concluídas. Ainda que haja aqueles que relatam seus percursos, nem sempre é prudente se fiar em suas confissôes. Leonardo da Vinci lhe aparece como uma exceção, na medida em que teve conservados seus manuscritos. Como é sabido, esses manuscritos, exceto algumas gravuras e alguns fragmentos de textos, permaneceram desconhecidos por quase quatro séculos, período durante o qual seu autor foi conhecido apenas como um brilhante artista.

Foi somente a partir do final do século XIX, com a publicação das ediçóes de Jean-Paul Richter e Charles Ravaisson-Mollien, entre outros, que sua obra se tornou objeto de estudos metódicos. "A impressão produzida por essas publicaçôes foi considerável” e "[...] o personagem Leonardo adquiriu proporçóes sobre-humanas” (KOYRÉ, 1973, p.102). Como, à época, não se tinha conhecimento da ciência medieval e renascentista, Leonardo foi tomado como o precursor da ciência e da técnica modernas. Essa foi a imagem dominante na primeira metade do século XX, e Duhem, de certa forma, partilhou dessa visão. Ele afirma, citando Félix Ravaisson, que Leonardo "[...] bem mereceu ser chamado 'o grande iniciador do pensamento moderno'." (DUHEM, 1984, v. I, p. 50). Sua posição, entretanto, foi muito distinta dos demais historiadores quanto ao estudo dos manuscritos leonardescos, que lhe propiciaram uma excelente ocasião para analisar como se deu a evolução do conhecimento científico, em um processo no qual a existência de contribuição científica medieval lhe pareceu inegável. Koyré (1973, p. 102) fala na "dupla descoberta" de Duhem: a da ciência medieval e a de elementos medievais no pensamento de Leonardo. Como um grande estudioso da revolução científica, Koyré entendeu que a defesa da continuidade do desenvolvimento científico em Duhem implicava necessariamente a negação da ocorrência de uma ruptura entre a ciência medieval e a ciência moderna ${ }^{3}$. Leonardo, a seu ver, passaria a ser visto por Duhem como "[...] um elo - o elo mais importante - entre a

\footnotetext{
${ }^{3}$ A caracterização de um antagonismo entre uma posição continuísta, associada normalmente à perspectiva de Duhem e Sarton, e uma posição descontinuísta, à qual se ligam os nomes de Koyré e Kuhn, é facilmente encontrada na filosofia e na história da ciência. Ver, por exemplo, Bernard Cohen (1987, p. 202-203; COHEN 1994 [1985], p. 22 e 562), Maiocchi (1985, p. 277-279) e Preston (2008, p. 54). Sobre o suposto antagonismo entre Duhem e Kuhn, no que diz respeito ao desenvolvimento da ciência, ver Oliveira (2012).
} 
Idade Média e os tempos modernos" (KOYRÉ, 1973, p. 103), deixando de ser apresentado como um "gênio único".

É com referência à admiração pelos gênios da ciência que Pierre Duhem inicia sua extensa obra sobre Leonardo - Études sur Léonard de Vinci: ceux qu’il a lus et ceux qui l'ont lu -, publicados em três volumes, entre 1906 e 1913 ${ }^{4}$. Logo no início dessa obra, o autor comenta o sentimento de admiraçáo e espanto que experimentamos diante de uma grande descoberta científica: "[...] nosso olhar atônito mede a altura à qual o gênio se elevou; nós sentimos a que ponto essa altura ultrapassa todas aquelas a que nosso humilde espírito poderia atingir e uma espécie de vertigem se apodera de nós" (DUHEM, 1984, v. I, p. III). Ao mesmo tempo em que se mostra compreensivo com esse sentimento de admiração e espanto em face da obra dos grandes cientistas, Duhem se esforça por se colocar em uma situação distinta de outros historiadores que, em seu ponto de vista, evidenciaram uma visão superficial e enganadora do empreendimento científico, sobretudo no que se refere ao trabalho dos gênios. E Leonardo da Vinci lhe parece um exemplo bastante privilegiado para corrigir essa visão.

A primeira condição para se analisar a revisão histórica duhemiana acerca do gigante Leonardo é a colocação das características centrais que determinavam a visão histórica da obra do grande artista. Assim, temos de buscar resposta à questão: qual a visão que Duhem alega ser a dominante, em seu tempo, sobre Leonardo da Vinci e o papel que o renascentista teve no desenvolvimento da ciência? Para responder a essa questão, de modo a esboçar um quadro que reflita as características essenciais que determinavam a visão a propósito de Leonardo, empregamos a descrição do próprio Duhem, presente no início de seus Études. Leonardo da Vinci era visto como o "autoditada

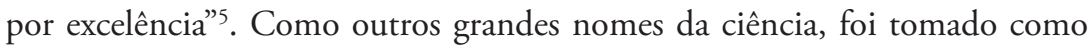
responsável por uma obra colossal, nascida de uma geração espontânea, incompreensível e extremamente isolada em seu tempo e espaço. Toda sua obra em mecânica e física se devia unicamente às suas experiências e meditaçóes (DUHEM, 1984, v. 1, p. 1-2). Diante desse quadro, é possível indagar: como Leonardo poderia ser visto de modo diferente, face à perspectiva histórica então vigente, que contrapunha a Renascença à Idade Média, em detrimento dessa última? Essa é a questão de Duhem (1984, p. 2):

\footnotetext{
${ }^{4}$ Doravante também denominados de Études.

${ }^{5}$ Duhem (1984, V. 1, p. 1) cita a caracterização de Eugène Müntz com a seguinte referência: "Eugène Müntz. Léonard de Vinci, l'artiste, le penseur, le savant. Paris, 1899, p. 278”.
} 
Para que se informar sobre aqueles que poderiam ter sido seus precursores? Não viviam eles naquela obscura Idade Média, em que a palavra de Aristóteles tomava o lugar do pensamento? Como aquela Escolástica estéril poderia ter sugerido, ao grande artista de Vinci, as ideias novas e frutíferas que são abundantes em suas notas?

A revisão da obra de Leonardo da Vinci, para Duhem, pressupóe uma completa modificação da concepção do desenvolvimento científico que alterava substancialmente a avaliação histórica da Idade Média, vista como infrutífera, e também da Renascença, considerada como um período áureo, de preparação para a Idade Moderna. Seus Études trazem uma nova visão dos personagens e dos cenários, já bem caracterizados na história da ciência. E, embora Duhem se demonstre crítico com respeito à história da ciência que subestima a contribuição dos medievais e exalta a dos renascentistas, ele raramente indica nomes dos responsáveis por essa história. Em seus Études, além de Müntz, ele se refere criticamente à obra de G. Libri ${ }^{6}$. Leonardo não foi absolutamente um autodidata (DUHEM, 1984, v. 1, p. 123). É verdade que uma pessoa que, ainda que uma só vez, tivesse folheado seus manuscritos, não colocaria em dúvida a originalidade com a qual ele tratou uma série de problemas científicos - diz Duhem (1984, v. 1, p.1) - mas é legítimo “[...] perguntar se a natureza e o caráter dessa originalidade foram estudados com cuidado suficiente". Com zelo e reflexão, é possível lidar com a admiração e o assombro, sempre presentes diante das obras do grande gênio, uma vez que, na medida em que uma grande descoberta se torna mais familiar a nós, a nossa admiração "[...] muda de natureza. Certamente ela não perde sua intensidade, mas se despoja, pouco a pouco, de tudo o que a surpresa misturou de indistinto e de irrefletido; ela se torna cada vez mais consciente e razoável"

\footnotetext{
${ }^{6}$ Para indicar um erro do autor com relação à interpretação de Leonardo, Duhem (1984, v. 1, p. 36, n. 1) alude à "habitual inexatidão" de Libri, cuja obra Histoire des Sciences mathématiques en Italie (1840) apresenta um estudo da obra de Leonardo da Vinci (v. III). Aí se pode notar o tratamento enaltecedor do autor sobre o "gênio sublime" que foi Leonardo, em referências explícitas ao acolhimento da visão difundida por Vasari (citado muitas vezes no texto). Vale lembrar ainda que a obra de Libri é a referência indicada por Burckhardt (1991, p. 213) como a "literatura especializada" em ciências naturais, ainda que com ressalvas. Outros textos publicados antes de Duhem atentar para a existência da contribuição medieval podem ser tomados como exemplo da visão de Leonardo enquanto homem de saber fenomenal, pertencente a uma época que substituía a superstição e a autoridade pela observação e o método experimental. Um bom exemplo é o de Thayer (1894), que descreve Leonardo como um pioneiro na recusa da autoridade dos antigos, da superstição e dos "absurdos" da Idade Média e, ainda, como inaugurador do método experimental. Para uma reflexão mais ampla sobre os possíveis alvos da crítica duhemiana em relação à história que ignora as contribuições medievais, ver Oliveira (2012, p. 35-52).
} 
(DUHEM, 1984, v. 1, p. III). Podemos perceber, então, assegura Duhem, que Leonardo náo foi um homem isolado em seu tempo e lugar, mas que recebeu influências de outros pensadores, influenciou outros, enfim, esteve inserido em uma tradição contínua do desenvolvimento científico.

A história da ciência, segundo Duhem, é prejudicada por aqueles que ignoram o fato de que a ciência não conhece geração espontânea e nem dá saltos bruscos (DUHEM, 1984, v. I, p. 156); é, deturpada porque sofre de dois preconceitos que, de tão semelhantes, poderiam ser tomados como um único: o de que o progresso científico se processa por uma série de descobertas repentinas e imprevistas e de que a obra dos gênios não tem precursores. Duhem (1984, v. 1, p. IV-V) reconhece que a reconstituição desse processo contínuo não é uma tarefa simples para o historiador, o qual nem sempre dispóe de documentos que revelam o processo gradativo do desenvolvimento das ideias científicas.

Os manuscritos de Leonardo da Vinci têm, pois, para Duhem, um valor inestimável, pois lhe permitem investigar o processo evolutivo do pensamento do grande cientista e explicitar como sua obra é, ao mesmo tempo, produto de esforços realizados anteriormente por outros homens e uma etapa necessária para os avanços que lhe seguem. Este é o grande empreendimento a que Duhem se propóe em Études, nos quais encontramos uma grande diversidade de temas explorados, distribuídos em recortes por capítulos ou pequenas seçóes dentro desses capítulos. De modo geral, os estudos duhemianos sobre Leonardo não são apresentados em ordem cronológica. Os capítulos aparecem como independentes dos demais e, às vezes, é possível perceber certa repetição de conteúdo já explorado. Exemplos disso são o primeiro e o oitavo capítulos do primeiro volume, dedicados à investigação do trabalho de Alberto da Saxônia 7 .

O primeiro capítulo, sobre o escolástico da Saxônia, pode ser tomado como exemplo da tentativa duhemiana de reescrever a história da ciência, de modo a argumentar em prol da continuidade da tradiçấo científica e da necessária revisão da contribuição medieval. A tarefa inicial a que se dedica é a inserção do desconhecido Alberto da Saxônia na história da ciência, com apresentação de dados biográficos. Reivindicando-lhe um lugar de destaque entre os doutores escolásticos do século XIV, Duhem aborda aspectos de sua física, que teriam chamado a atenção de Leonardo da Vinci. Alberto da

\footnotetext{
${ }^{7}$ Martin (1991, p. 159) chama a atenção sobre o aspecto fragmentário da obra, que, segundo ele, consiste, em sua grande parte, de artigos publicados em periódicos e dirigidos à acumulaçáo de evidências em favor da ciência medieval.
} 
Saxônia, segundo Duhem, teria tentado resolver as dificuldades identificadas nas explicaçóes aristotélicas acerca da determinação do lugar natural da Terra. Na sequência, Duhem (1984, v. 1, p. 21-22) alude ao que Leonardo teria aproveitado da teoria do escolástico e, com menção ao "caderno F dos manuscritos", indica que o grande gênio havia anotado referências aos escritos de Alberto da Saxônia.

Ao discutir a plausibilidade de se tomar como autênticas as relaçóes que estabelece entre os dois cientistas, Duhem cita a seguinte passagem dos manuscritos de Leonardo, a qual não deixaria dúvidas de que o grande gênio leu o escolástico: "Alberto da Saxônia diz, em Das proporçóes, que se uma força move um móvel com certa velocidade, ela moverá a metade desse móvel duas vezes mais rápido. Não me parece assim...” (LEONARDO DA VINCI apud DUHEM, 1984, v. 1, 22).

A análise duhemiana, além de abordar a influência de um pensador sobre o outro, destina-se a mostrar o que Leonardo acrescentou às ideias de seu precursor e o desenvolvimento que proporcionou à ciência ao recusar determinadas soluçóes, propondo outras inovadoras. As duas últimas seções do capítulo são destinadas, respectivamente, à análise do que Leonardo acrescentou (seção IV) e ao que ele se opôs quanto às doutrinas de Alberto da Saxônia (seção V). Sem entrar no mérito de discutir detalhadamente cada argumento empregado nessas seçôes, interessa-nos analisar o esforço duhemiano por estabelecer uma nova visão histórica do desenvolvimento da ciência, a partir dos manuscritos de Leonardo.

Após apresentar o que considera indícios da influência de Alberto da Saxônia sobre Leonardo da Vinci, questiona Duhem: "Pode-se desejar prova mais surpreendente da continuidade pela qual se desenvolve a ciência?" (1984, v. I, p. 50). Leonardo da Vinci, que foi retratado pelos historiadores que se ocuparam da Renascença como um gênio gigante isolado em seu tempo e autodidata por excelência, aparece-lhe como um herdeiro das contribuiçóes dos medievais, do "[...] movimento intelectual, intenso e prolongado que foi a escolástica” (DUHEM, 1984, v. 1, p. 50) e como um precursor de muitos cientistas modernos.

Os Études passaram a ser uma referência em história da ciência para o reconhecimento da grande contribuição de Pierre Duhem na reavaliação da Idade Média. Esse reconhecimento, que se tornou trivial, é explícito entre seus intérpretes, seja entre defensores, seja entre os seus mais acirrados 
opositores. Discussóes sobre as revisões da contribuição científica medieval são cenários certos para a aparição de Duhem como um importante personagem na história. É assim, por exemplo, que Ferguson (1950, p. 167) o considera o líder do que denominou "a revolta dos medievalistas"; que Crombie (1969, p. 79-80) menciona suas "aventuras heroicas" na ciência medieval, ao discutir o problema das relaçóes da ciência do século XVII com a ciência medieval como uma questio disputata.

Os estudos duhemianos também se tornaram uma referência obrigatória para a discussão sobre o papel de Leonardo da Vinci no desenvolvimento científico. Contudo, da mesma maneira como a nova visão da Idade Média não passou ilesa, inicialmente, às mais severas críticas, também o retrato que Duhem forneceu de Leonardo não agradou seus contemporâneos e sucessores. Aliás, a maior ressalva à visão histórica de Duhem tem como cerne uma suposta exacerbação indevida da contribuição medieval, marcada por um anacronismo característico, conduzida por motivações apologéticas. É o que podemos perceber nas críticas dos intérpretes de Leonardo que estiveram igualmente empenhados em mostrar dele um novo retrato.

\section{George Sarton: DO PROJETO DE UMA “ENCiClopédia LEONARdesca” À RESIGNAÇÃO DO FORNECIMENTO DE “UM CATÁLOGO” SOBRE LEONARDO}

Poucos anos depois de Duhem ter publicado seu terceiro volume de Études, George Sarton anuncia, em 1919, no fascículo X, de Raccolta Vinciana, o projeto de apresentar ao público um grande estudo sobre Leonardo da Vinci, cujo título seria An encyclopaedic survey of artistic, scientific and technical thought at the heigh of the Italian Renaissance. O projeto era grandioso: a obra compreenderia três partes e talvez o mesmo número de volumes. Uma parte, geral e sintética, seria de interesse dos historiadores da Renascença e do público em geral; outra parte, especial e analítica, conteria uma série de capítulos consagrados a uma ciência ou técnica especial: astronomia, geologia, mecânica, matemática, botânica etc. Todos os capítulos seriam preparados pelo próprio Sarton, com exceção dos estudos de anatomia e fisiologia. A terceira parte conteria um índex e apêndices críticos, os quais, em conjunto, comporiam uma espécie de dicionário com os temas que importavam no tempo de Leonardo. As duas partes últimas seriam de interesse dos historiadores da ciência, já que seu trabalho permitiria náo somente a análise de assuntos científicos do período da Renascença, mas também o acompanhamento da evolução 
desses assuntos, durante todo o período que antecede Leonardo, o medievo. Essas características são apontadas por Sarton no anúncio de seu projeto. Sua ambição "[...] era de oferecer ao mundo culto uma espécie de enciclopédia leonardesca" - um trabalho "[...] indispensável para a compreensão exata da Renascença” (SARTON, 1919, p. 237).

Sarton intentava estudar não somente as ideias de Leonardo e seus contemporâneos, mas explicitar a gênese e a evolução de suas contribuiçôes para a ciência, o que implicava o estudo da filosofia medieval cristá, árabe e judaica (SARTON, 1919, p. 238). Seu projeto incluía ainda a preparação de uma "[...] edição completa dos escritos de Leonardo, publicados não por manuscritos, mas em uma ordem sistemática de assuntos" (SARTON, 1919, p. 240).

Dez anos após o anúncio do projeto, Sarton (1930, p. xv) afirma saber que faltam muitos anos para que ele possa finalmente escrever sobre Leonardo, já que havia se equivocado quanto ao tempo necessário para falar de seus antecedentes medievais. Em outro texto, publicado trinta anos depois, "A Summing Up"8, Sarton (1962, p. 367) relata o desfecho de seu projeto de estudar as realizaçóes de Leonardo da Vinci, lembrando que, à época de seu empreendimento, havia percebido que o renascentista, muitas vezes denominado "o pai da ciência moderna, era a criança da Idade Média" e que, portanto, para bem compreender seu pensamento, era necessário um conhecimento aprofundado da ciência medieval. A tarefa de estudar a ciência século por século, até Leonardo, consumiu-lhe muito mais tempo do que o estimado e ele não chegou a atingir a época pretendida, parando suas pesquisas por volta do ano de 1400 (SARTON, 1919, p. 367-368). O resultado foi a realização de uma grande obra, Introduction to the History of Science ${ }^{9}$, na qual Sarton teria se esforçado por fornecer um estudo minucioso dos antecedentes de Leonardo (STIMSON, 1962, p. xv).

Embora Sarton não tenha efetivado seu projeto grandioso ${ }^{10}$, o que ele escreveu sobre Leonardo em alguns textos (SARTON, 1919, 1948, 1957, $1962^{11}$ ) fez dele uma referência no que se refere à história de Leonardo da Vinci.

\footnotetext{
${ }^{8}$ Parte do relatório final para a Carnergie Institution, de Washington, na qual Sarton permaneceu como pesquisador associado de 1918 a 1949.

${ }^{9}$ Cinco partes, publicadas em três volumes (1927, 1931 e 1947).

${ }^{10}$ Pinto de Oliveira e Oliveira discorrem sobre as aspirações de Sarton com relaçáo à obra de Leonardo da Vinci, em "Kuhn, Sarton, and the History of Science" (no prelo).

${ }^{11} \mathrm{O}$ texto de 1957 é uma versão em inglês (pouco modificada) do texto "Leonardo da Vinci, engénieur et savant", publicado no volume que reúne os trabalhos apresentados no colóquio em comemoraçấo ao
} 
A caracterização que faz das atividades de Leonardo expressa uma determinada concepção de ciência que guia sua narrativa histórica. E Leonardo lhe aparece como personagem exemplar na história da ciência, para tratar da evolução e progresso, da unidade e da beleza; para, enfim, "[...] humanizar a ciência" (SARTON, 1919, p. 236).

Quando anuncia o projeto de uma enciclopédia leonardesca, Sarton (1919, p. 239) refere-se a trabalhos históricos anteriores que lhe seriam fontes importantes de estudo. Dentre eles, os Études duhemianos aparecem com bastante destaque. É interessante analisar a visão que Sarton exibe desses estudos, na medida em que podemos verificar dois aspectos distintos: de um lado, o seu reconhecimento de uma dívida com Duhem em face do seu estudo da ciência medieval e a decorrente partilha de uma visão sobre o desenvolvimento contínuo da ciência; de outro lado, uma grande resistência quanto à nova avaliação histórica da Idade Média que emerge nos Études e à consequente caracterização das atividades científicas do gênio renascentista.

Do ponto de vista da partilha, Sarton se coloca ao lado de Duhem, quando afirma que Leonardo "[...] não é um acidente isolado, um milagre" (SARTON, 1919, p. 238), mas fruto de uma evolução contínua. Defendendo que as ideias em ciência "[...] não são (e nem podem ser) completamente originais, que náo são criaçôes ex nibilo", Sarton (1919, p. 239) concorda com a perspectiva duhemiana de que Leonardo, de alguma maneira, continuou ou renovou as tradiçóes antigas. Mas os pontos de concordância em relação à obra duhemiana se limitam a esses aspectos em "Une encyclopédie léonardesque".

Se Sarton (1919, p. 240) reconhece uma dívida "imensa” com Duhem, ele declara total desacordo com as suas conclusóes e pontos de vista no que concerne aos estudos sobre Leonardo da Vinci. A seu ver, Duhem não se colocaria como um historiador imparcial, mas como um defensor de uma causa, forçando comparaçôes entre Leonardo e os escolásticos parisienses e outros, por meio de repetiçóes de aproximaçóes que ele julgou estabelecidas. Para Sarton (1919, p. 240), de leitura enfadonha, que explicita a falta de homogeneidade dos escritos esparsos, repetitivos e, às vezes, contraditórios, a obra Études sur

V centenário do nascimento de Leonardo da Vinci, realizado em 1952, em Paris - Léonard de Vinci et l'expérience scientifique au XVI' siècle. O texto de 1962 foi publicado na seleçáo de textos editados por Dorothy Stimson, que informa ser uma versão ampliada do texto "Leonardo da Vinci", publicado pelo Metropolitan Museum of Arts, em 1952. 
Léonard de Vinci “[...] se relaciona mais diretamente à escolástica medieval do que a Leonardo, embora seu título exprima o contrário"12.

Duhem, segundo Sarton, conhecia apenas parte dos manuscritos e, portando, seus estudos náo poderiam ser completos. E, a despeito de as aproximaçóes que Duhem sugere entre Leonardo e outros pensadores serem interessantes, embora não seja possível negar que o gênio "[...] tenha emprestado parte de suas ideias, diretamente ou não, conscientemente ou não, de seu círculo ou do passado", que essas ideias sejam, "[...] em parte, notas de leitura ou de conversas ou de sugestóes de seu meio" (SARTON, 1919, p. 239), não seria possível provar como ele sugere.

As críticas a Duhem são bastante gerais nesse texto. Como Sarton não pôde desenvolver a sua enciclopédia leonardesca, não pôde também discutir o modo como Leonardo pôde (ou náo) ter sido influenciado em suas ideias; não pôde explicitar o que considerou contraditório no texto de Duhem, nem por que não partilhava de suas conclusôes e pontos de vista. E, embora Sarton não mencione mais o nome de Duhem nos outros textos específicos que escreveu sobre Leonardo, podemos perceber nitidamente aspectos que marcam as diferenças entre os pontos de vista dos dois historiadores, quando analisam a contribuição científica do renascentista.

$\mathrm{O}$ aspecto central de discordância entre eles é dado pela motivação maior de seus trabalhos referentes a Leonardo. Duhem empreendeu os Études, objetivando mostrar a importância da ciência medieval para a ciência moderna. Leonardo aparece-lhe como um continuador, como um "[...] elo admiravelmente sólido e brilhante” (DUHEM, 1984, v. 1, p. 123), no curso da evolução das ideias científicas. Sarton (1957, p. 233) expressou predileção clara pela ciência moderna ${ }^{13}$. Leonardo, “[...] um defensor da razão, um inimigo da superstiçâao", poderia ser visto como um construtor de uma ponte "[...] entre o pensamento medieval rudimentar e o racionalismo moderno", afirma Sarton (1962, p. 147), que revela uma mudança de perspectiva quando

\footnotetext{
${ }^{12}$ Encontramos a mesma consideração no prefácio que Sarton escreveu ao livro de Playfair McMurrich. Ver Sarton (1930, p. XV).

${ }^{13}$ Ao explicitar o plano de estudo da ciência medieval, em Introduction to the History of Science, Sarton (1927, p. 14) afirma: "Não tenho a pretensão de ser um medievalista. Sou simplesmente um historiador da ciência e o período que mais me interessa é o moderno". Na sequência, esclarece que os séculos XVIII e XIX correspondem ao período de que se ocupa, no ensino na Universidade de Harvard, enfatizando o "progresso tremendo" do último século, que permite olhar para o universo "[...] de um ponto de vista muito mais elevado".
} 
passou a reconhecer a importância do estudo da ciência medieval para a compreensáo do estado do conhecimento em seu momento presente:

\begin{abstract}
Por muito tempo, realmente, como muitos homens de ciência, não tive interesse pelos feitos dos estudiosos medievais. Pensava na Idade Média somente como "idade das trevas", um tempo de regressão, de perversidade intelectual, que era melhor esquecer completamente. Parecia um desperdício de energia procurar algumas pérolas nessa pilha enorme de lixo. Mais tarde, quando minha própria percepçáo histórica se desenvolveu, me tornei necessariamente mais inquisitivo. (SARTON, 1927, p. 15).
\end{abstract}

Contudo, enquanto um historiador que se debruça sobre os feitos dos estudiosos medievais, Sarton (1927, p. 16) se opóe aos "medievalistas", os quais, com muito poucas exceçóes, estariam desconsiderando o progresso da ciência. Obscurecidos pela filosofia escolástica, não seriam capazes de "perceber os fatos mais originais", as principais questôes científicas, enfim: os medievalistas tinham uma "concepção errônea da ciência". Com essa consideração, ele sugere que o historiador deveria investigar o passado com uma concepção de ciência dominante no seu momento presente.

Assumindo que a ciência moderna é o campo do progresso exequível via método experimental, Sarton defende que a pesquisa histórica do medievo revela que, nesse período, a “[...] soma do conhecimento positivo [...] era extremamente pequena em quantidade e qualidade. Havia pouca oportunidade para indução, e o conhecimento, sob a influência escolástica, tomava quase exclusivamente, uma forma dedutiva" (SARTON, 1927, p. 24). É assim que Leonardo, para Sarton, pode ser visto como construtor de uma ponte entre continuidades de domínios tão distintos: o domínio da superstição, da desrazão, da esterilidade, dos grilhôes da escolástica, por um lado, e, por outro, o domínio do progresso do conhecimento positivo, da liberdade de pensamento e da vitória da razão. De modo geral, podemos afirmar que Sarton, ainda que passasse a reconhecer a importância do estudo da ciência medieval, conservou, sobretudo em seus primeiros textos, uma caracterização histórica depreciativa da Idade Média.

Os textos que escreveu sobre Leonardo mantêm, talvez em nuances de menores intensidades, progressivamente, a oposição entre os dois períodos, com claro julgamento de valor, sustentado por uma determinada concepção de ciência em voga. No texto "Leonardo da Vinci e o nascimento da ciência moderna", de 1948, o renascentista é retratado como um artista, cientista 
e engenheiro que se interessou por muitas áreas do $\operatorname{saber}^{14}$ e que buscava o conhecimento na natureza e não nos livros:

Temos aqui um homem de considerável inteligência nata, mas inculto, simples, e que tinha considerado todas as questôes bem no seu início, como uma criança. Leonardo abriu seus olhos e olhou direto para o mundo. Não havia livros entre a natureza e ele; estava livre de preconceitos e convenções pelo aprendizado. Fez questóes apenas a si mesmo, realizou experimentos e usou seu senso comum. O mundo era único para ele, bem assim como a ciência e a arte. Mas ele não se perdeu em contemplação estéril ou em generalidades verbais. (SARTON, 1948, p. 75).

Diferentemente dos cientistas medievais, Leonardo tinha a mente imune às "falácias escolásticas", não foi dogmático (SARTON, 1948, p. 77) e demonstrou uma atitude completamente inovadora e avançada em seu tempo com relação ao método da ciência:

Ele tentou resolver pacientemente cada pequeno problema em separado. Viu que o único caminho frutífero de fazer isso é primeiro formular o problema tão claramente quanto possível, entâo isolá-lo, fazer os experimentos necessários e examiná-los. $\mathrm{O}$ experimento é sempre o fundamental; a matemática, isto é, a razão, no fim. Em resumo, Leonardo tinha praticado efetivamente o método da filosofia indutiva que Francis Bacon iria explicar tão bem um século e meio mais tarde. (SARTON, 1948, p. 75-76).

Quando compara Leonardo a outros cientistas, Sarton busca fazêlo em relação aos cientistas modernos, diferentemente de Duhem. Ao fazer comparaçóes a propósito das obras dos medievais, é claro o sentimento de menosprezo por elas. Tome-se como exemplo a seguinte comparação dos manuscritos de Leonardo com os escritos de um cientista medieval:

É necessário insistir que a maioria desses desenhos e notas de Leonardo não são esquemas inúteis, sugestôes vagas e fáceis como nós encontramos, por exemplo, nos escritos de Roger Bacon; mas, pelo contrário, ideias muito claras e definidas que poderiam ter sido patenteadas, se já existisse algo como um escritório de registro de patentes! $!^{15}$ (SARTON, 1948, p. 73-74).

\footnotetext{
${ }^{14}$ Sarton menciona as contribuiçôes de Leonardo para diversas áreas do conhecimento, as quais, enquanto áreas de especialização, só viriam a existir séculos depois: botânica, geologia, metalurgia, administração científica etc.

${ }^{15}$ Outras comparaçōes podem ser encontradas nesse texto, em que Sarton $(1948$, p. 80) caracteriza A Divina Comédia como "sublime apoteose da Idade Média" e os manuscritos de Leonardo como
} 
Leonardo, segundo Sarton (1948, p. 73), “[...] viu claramente que teoria e prática são irmás gêmeas que devem se desenvolver juntas; que teoria, sem prática, é sem sentido, e a prática, sem teoria, inútil”. Contudo, Leonardo não emprestou teorias nem teve a mente moldada por professores, simplesmente porque, de acordo com Sarton (1948, p. 77). , ele

[...] foi criado entre os experimentos do estúdio [de Verrocchio] e a vida real, não entre as artificialidades de uma biblioteca medieval. [...] Foi original demais, impaciente demais. Se começasse a ler, alguma ideia atravessava sua mente e desviava sua atenção e o livro era abandonado [...] naquele tempo, sua mente já estava imune às falácias escolásticas; ele era capaz de filtrar, pela própria experiência, qualquer filosofia medieval que o atingisse, seja impressa ou oral. ${ }^{16}$

Podemos notar, nessa passagem, uma recusa da visão expressa nos Études de Duhem, não mencionado explicitamente, como já afirmamos, em nenhum outro texto de Sarton sobre Leonardo, além daqueles de 1919 e 1930. Para Sarton, a cultura medieval foi nociva e a Renascença não foi somente um retorno aos antigos, foi, antes, um retorno à natureza, o que representou uma verdadeira revolução, um milagre resultante da conjunção do "espírito de artesanato" e do "experimento na busca pela verdade". E, ainda conforme Sarton, foi aí "[...] que a ciência moderna nasceu, mas infelizmente Leonardo permaneceu em silêncio e seus profetas vieram somente um século mais tarde” (SARTON, 1948, p. 78).

Embora considere que Leonardo tenha sido uma ponte entre o conhecimento medieval e o moderno, Sarton busca reiterar a particularidade do caráter do renascentista, mantendo, de certa forma, a descrição do gênio isolado.

sendo não "simplesmente um epítome do passado", mas uma obra que já "contém as sementes do futuro". Para Sarton, o mundo de Dante "foi o mundo fechado medieval", o de Leonardo, "o ilimitado mundo do homem moderno"; Dante foi "um amante tímido", enquanto Leonardo foi "um herói conquistador" da verdade.

${ }^{16}$ É interessante observar que Sarton, ao mesmo tempo em que critica a história de Duhem, alegando ser impossível provar que Leonardo tenha lido os medievais, elabora sua narrativa histórica com muitas suposiçóes. As passagens que seguem expressam isso mais claramente: "Aconteceu que, durante esses quatro anos, ele não realizou muito trabalho anatômico. Cadáveres eram sempre difíceis e suponho que, quando ele podia se apossar de um, fazia o máximo dele, trabalhando dia e noite, tão rápido quanto podia" (SARTON, 1948, p. 74). Em Sarton (1953c, p.12), lemos: "Em 1512, Milăo foi reconquistada pelos italianos e Leonardo foi obrigado a se mudar (imagino como ele foi compromissado como 'colaborador')". A parte final de seu texto "Leonardo da Vinci e o nascimento da ciência moderna" (1948) apresenta uma grande suposição do que diria Leonardo em seu tempo acerca de suas condiçôes e de seus anseios científicos. 
Ainda que reafirme a continuidade da tradição científica, é possível verificar sua reação contra a tentativa de estabelecer elos entre precursores, contemporâneos e sucessores imediatos. A ponte só pode ser divisada em análise global, após o grande desenvolvimento da ciência moderna. Assim, afirma Sarton (1953c, p. 14), poderia ser equivocado tomar Leonardo como o "precursor de Copérnico ou Harvey", mas não como "um dos pioneiros da aviação".

Consideraçôes que relativizam as supostas influências que Leonardo teria sofrido e exercido em relação a outros cientistas estão presentes nos textos que Sarton publicou após os anos 1950. Ainda que implícita, permanece a crítica à visão duhemiana apresentada em Études. É o que se pode observar na passagem que segue:

Ele [Leonardo] continuou uma tradição medieval que remonta até Aristóteles e Arquimedes, mas que foi extremamente irregular, caprichosa e sigilosa. Conhecia ele os escritos antigos e medievais relativos à mecânica pura? É muito improvável. Entretanto, ele cita Arquimedes meia dúzia de vezes e também Biagio Pelacani [...] e Alberto da Saxônia [...]. Isso não prova muito. Todos esses escritos estavam em latim e o conhecimento de latim de Leonardo era empírico e inegavelmente imperfeito. Ele era quase iletrado, lia muito pouco e citava menos ainda. (SARTON, 1953c, p. 14).

$\mathrm{Na}$ defesa de que as notas de Leonardo eram esparsas, não desenvolvidas, de que ele tenha vivido em uma tradição oral e manual e não literária, Sarton (1953c, p. 11) sustenta sua recusa da possibilidade de denominá-lo precursor de Copérnico, sob o "simples argumento" de que Leonardo tenha escrito em uma passagem que o sol não se move. Diz Sarton: "Um sábio não é um profeta; é necessário que ele prove ou, ao menos, que explique claramente o que quer dizer" (SARTON, 1953c, p. 11) ${ }^{17}$. Como se pode observar, Sarton analisa a atividade científica leonardesca a partir de critérios que ditam o que é a ciência em 1952, no ano da comemoração do V centenário do nascimento de Leonardo.

Pode soar contraditório que Sarton tenha se empenhado tanto por escrever sobre Leonardo, um exemplo de mente livre, de experimentalista, de "[...] um dos maiores homens de ciência" (SARTON, 1962, p. 141), e afirme que sua influência científica "[...] foi mínima, porque ninguém sabia exatamente o que ele estava fazendo" (SARTON, p. 1962, p. 142); que o desenvolvimento da anatomia (1953c, p. 19) e da mecânica (1953a, p. 114)

${ }^{17}$ Em outra passagem, Sarton (1953c, p. 14). enfatiza que, para Leonardo, era “[...] impossível resolver os problemas fundamentais, pois eles não podiam ainda ser formulados". 
teria sido o mesmo "[...] se Leonardo não tivesse existido", que as sementes que ele plantou não vingaram porque ele nada publicou (SARTON, 1953c, p. 18), que "[...] sua real influência como cientista e pensador data somente a partir do século XIX.” (SARTON, 1962, p. 142).

Além disso, Leonardo, mesmo sendo estudante da natureza e não de livros, não pôde ir além, porque esteve preso aos preconceitos platônicos e galênicos dominantes em sua época. É assim que, de certa forma, Sarton (1962, p. 136-138) parece estar ciente do suposto aspecto paradoxal de sua obra histórica sobre o renascentista, quando indaga a respeito do lugar de Leonardo na história da ciência, após falar dos citados preconceitos:

Isso levanta uma questão problemática: Leonardo foi realmente um descobridor científico, um homem criativo de ciência? Merece ser listado entre os grandes homens da ciência do passado?

A colocação dessas questões pode chocar seus admiradores. Seu gênio científico não é questionado nem tampouco sua devoçáo para assuntos científicos. Não se pode negar que muito de seu trabalho foi aquele de um homem de ciência ou técnico, mais do que o de um artista. Então você deve perguntar por que eu levanto essa questáo. (SARTON, 1962, p. 138).

A resposta à questão problemática dependerá, para muitas pessoas, do que se entende por "descoberta científica", e a reposta de Sarton é condizente com aquela que segue os parâmetros da ciência moderna: um processo complexo, que exige provas e só finda com a aceitação da comunidade científica - em suas palavras, com a aceitação de "juízes competentes" (SARTON, 1962, p. 138). Em síntese, porque Leonardo não publicou tratados, não conhecia bem o Latim, porque esteve preso a preconceitos etc., não é possível "[...] conferir crédito a ele por nenhuma descoberta científica, exceto talvez, pelo que está contido em seus desenhos anatômicos e mecânicos" (SARTON, 1962, p. 140-141).

Sarton (1953c, p. 20; 1962, p. 140) insiste em que Leonardo foi um uomo senza lettere; "[...] não foi um leitor nem mesmo escritor" (SARTON, 1962, p. 143); nunca se referiu a livros impressos e desprezou-os como tais, porque muitos dos escritos de seus contemporâneos "[...] eram escolásticos e retóricos - vazios" (SARTON, 1962, p. 143). A abundância de suas notas não deveria nos enganar; refletem as atividades de um homem prático que teve a felicidade de náo ter recebido uma formação tradicional e ter sido enviado ao estúdio de Verrocchio, onde teve uma educação livre de preconceitos. 
Mais de trinta anos após o anúncio do projeto de uma enciclopédia leornardesca, Sarton (1948, p. 71) pede desculpas ao leitor, por poder fornecer somente um catálogo dos feitos de Leonardo, já que qualquer tema que resolvesse explorar tomaria muitas páginas. Os pequenos textos que escreveu sobre o assunto apresentam consideraçôes gerais sobre a obra do grande gênio, as quais podem ser agrupadas em dois domínios: o de enaltecimento e o de lamento. De um lado, há a caracterização de "[...] um dos maiores homens de ciência" (SARTON, 1962, p. 141), o defensor da razão, inimigo da superstição (SARTON, 1953c, p. 22), que se interessou por tudo e deu de ombros para a tradição medieval escolástica, que pôde combinar - melhor que Goethe - a arte e a ciência (SARTON, 1959, p. 85), que representa o maior símbolo das aspiraçóes científicas da Renascença (SARTON, 1959, p. 85) e que teve o instinto do homem moderno na perseguição da verdade ${ }^{18}$.

De outro lado, ainda que afirme em um de seus textos que "Leonardo fez tudo o que poderia fazer em seu tempo" (SARTON 1953c, p.14), são manifestas suas lástimas por ele não ter sido completamente moderno. A seu ver, Leonardo não conseguiu superar completamente o peso da tradição antiga e medieval, não pôde se emancipar completamente de preconceitos platônicos e galênicos ${ }^{19}$ e, por esse motivo, não efetivou a descoberta da circulação do sangue, realizada mais tarde por Harvey ${ }^{20}$. Leonardo teria falhado em completar suas obras (SARTON, 1959, p. 88). Ao mesmo tempo em que Sarton (1962, p. 143) relativiza a "falha" de Leonardo "[...] em arte, ciência, tecnologia e escrita", buscando mostrar uma atitude compreensiva das razóes por que ele não pôde triunfar, seus textos estão repletos de consideraçóes valorativas que se guiam por um ideal de ciência - a moderna.

\section{LEONARDO DA VINCI 500 ANOS DEPOIS: NOVAS INTERPRETAÇÓES}

As visóes de Duhem e Sarton estão presentes de forma significativa no colóquio realizado em Paris, de 4 a 7 de julho de 1952, em comemoração ao $\mathrm{V}$ centenário do nascimento de Leonardo da Vinci, o que se pode observar no livro Léonard de Vinci et l'expérience scientifique au XVI' siècle, o qual reúne os

\footnotetext{
${ }^{18}$ Sarton (1953c, p. 21-22; 1962, p. 145-146) compara Leonardo com alguns de seus contemporâneos, como Dürer, para justificar a predileção que nutria por ele.

${ }^{19}$ Veja, por exemplo, Sarton (1962, p. 137, 140; 1959, p. 87; 1953c, p. 17).

${ }^{20}$ Pinto de Oliveira e Oliveira (no prelo) discutem o modo como Sarton aborda a "não descoberta" de Leonardo com relação à circulação do sangue.
} 
trabalhos expostos no evento. Já no início da obra, Lucien Febvre (1953, p. 5), em seu "Discurso inaugural", faz referências aos Études, mencionando a imagem construída por Duhem de um Leonardo savant, conjecturando se, apesar de "pleno de saber valioso", o livro não seria "viciado desde seu ponto de partida".

Podemos verificar que a maioria dos estudiosos participantes do colóquio menciona a obra de Duhem e que, de modo geral, apresenta diferentes posicionamentos em relação à visão exposta nos Études: o da citação sem restriçóes (por exemplo, Michel e Gille), o de mençóes com ressalvas (por exemplo, Santillana, Sergescu e Hooykas) e o de crítica predominante (Sarton, Febvre, Dugas e Koyré). É impossível elencar aqui todos os aspectos de concordância ou não dos estudiosos com Duhem. Um aspecto que toma conta da discussáo é se Leonardo tinha tido acesso ao pensamento dos antigos e/ou medievais, se tinha sido influenciado por eles e se influenciou os seus sucessores; em suma: se Leonardo foi ou não um gênio isolado.

Para Michel, Santillana e Sergescu, por exemplo, Leonardo certamente leu muito ${ }^{21}$; para Dugas, Hooykaas e Koyré, Leonardo certamente não era um iletrado e deve ter realmente sido um leitor, mas não da maneira exposta por Duhem. Dugas (1953, p. 92) interpreta os Études como repletos de exagero, ao ponto de afirmar que Duhem fez, de Leonardo, "[...] um rato de biblioteca saciado da escolástica". E, como Sarton, exalta a inovaçáo metodológica leonardesca, que antecipa Bacon e que recusa "[...] todo princípio de autoridade no domínio da ciência” (DUGAS, 1953, p. 89). Leonardo, a seu ver, teve insaciável curiosidade, liberdade de pensamento, demonstrou indiferença pelos retóricos e esteve alheio a qualquer preocupação livresca. Ainda como Sarton, Dugas vê Leonardo como um visionário que náo pôde edificar a ciência mecânica, porque foi autônomo e viveu em pleno isolamento, distante do esforço coletivo de que se nutrem as tradiçóes (DUGAS, 1953, p. 114).

Koyré (1953, p. 237-246), organizador do colóquio, em seu relatório final, opóe as visóes de Duhem e Sarton, quando avalia o evento como uma ocasião que proporcionou modificação e aprimoramento da imagem de Leonardo. No início de seu relatório, ele ressalta que se limitará a expor a impressão que o colóquio deixou:

Estranha sensação: a da presença de uma pessoa, de um pensamento, de um trabalho que tinha sido raramente mencionado, que mesmo por aqueles que o fizeram, não tinha sido discutido e que, portanto, - como

\footnotetext{
${ }^{21}$ Sergescu (1953, p. 81) vai mais longe: Leonardo tinha a intenção de escrever uma enciclopédia científica.
} Esse ponto de vista, como podemos observar, é extremamente estranho à perspectiva sartoniana. 
foi sugerido por G. de Santillana, pelo próprio título de sua comunicação, Leonardo da Vinci e aqueles que ele náo leu, parece dominar, ou pelo menos, orientar o nosso trabalho. Com efeito, essa é a função da obra admirável, embora altamente contestável, de Pierre Duhem e de seus Études sur Léonard de Vinci-ceux qu'il a lus et ceux qui l'ont lu, que parece colocar, ainda hoje em dia, o problema da interpretação da personalidade e da obra científica de Leonardo. (KOYRÉ, 1953, p. 237).

Koyré discute a função dos Études na revisão histórica acerca do papel de Leonardo. Duhem teria substituído a imagem mítica, a de um gênio isolado, por uma concepção rigorosamente histórica. A seguir, combate a visão de Leonardo como a de um erudito, fruto da tradição medieval e transmissor dessa tradição à ciência do século XVI e XVII. E se coloca ao lado de Sarton: foi com razão que esse historiador alegou que não se podia tirar conclusão de textos isolados dos manuscritos. Náo é porque Leonardo declarara, em algum lugar, que "o sol não se move", que se pode fazê-lo um precursor de Copérnico. Segundo Koyré, historiadores como Maier, Thorndike, Clagett, entre outros, e "[...] last not least, graças à obra imensa de Sarton" (KOYRÉ, 1953, p. 238), tornou-se possível conhecer, melhor que Duhem, o pensamento da Idade Média e o da Renascença. Koyré (1953, p. 238) evoca ainda a visão de Sarton para se referir à "[...] literatura científica e técnica em linguagem vulgar"; para reafirmar que Leonardo foi um "engenheiro artista”, "[...] um homem da práxis: um construtor de máquinas", "de atitude quase pragmática” que estabeleceu uma relação direta da ciência, encarada não como "[...] um objeto de contemplação, mas instrumento de ação” (KOYRÉ, 1953, p. 241). A aprendizagem no estúdio de Verrochio - que lhe proporcionou a discussão de problemas concretos e a execução de experimentos e inovaçôes - teria sido uma condição para a ocorrência do "milagre" Leonardo.

Podemos perceber que, além de Koyré e Dugas, outros estudiosos de Leonardo participantes do colóquio mencionam a visão sartoniana como fonte para suas colocaçóes. Sarton é apresentado como o presidente da União Internacional de História das Ciências (FEBVRE et al., 1953, p. VIII) e é o primeiro a expor uma comunicação. Em suas colocaçôes, conforme já comentamos, ele recusa a visão de Leonardo como precursor, reforçando o caráter solitário do gênio renascentista, "quase iletrado", que "[...] lia muito pouco e citava menos ainda”, um "uomo senza lettere"(SARTON, 1953c, p. 20). Leonardo não recebeu uma educaçáo acadêmica que carecia de contato com a realidade, mas, aprendiz de Verrocchio, pôde lidar com problemas tangíveis e 
reais (SARTON, 1953c, p. 12). De modo geral, a discussão da contribuição de Leonardo é levada adiante a partir da concepção de ciência após a revolução científica, ou seja, após o advento da ciência moderna. Retomando: Leonardo não foi um cientista, porque os problemas fundamentais da ciência ainda não podiam ser formulados e porque esteve preso a "preconceitos platônicos e galênicos" 22 .

Sarton reforça uma postura contrária à interpretação duhemiana da contribuiçấo científica de Leonardo, quando, em uma de suas intervenções (SARTON, 1953a, p. 114), levanta objeçóes à segunda parte do título do "famoso livro de Duhem [...] Leonardo, aqueles que ele leu e aqueles que o leram", porque "[...] quase nenhuma pessoa o podia ter lido antes do século XIX"23. Em outra intervençáo no debate, reclama universalidade para a história da ciência, argumentando que a análise dos precursores, contemporâneos e sucessores imediatos de Leonardo comporiam uma história italiana, enquanto um estudo dos predecessores de Leonardo sábio e inventor pertencia a todas as naçôes (SARTON, 1953b, p. 246).

A visão de Sarton predomina na análise que Koyré faz do colóquio, em seu relatório final, onde o historiador é evocado uma meia dúzia de vezes com o objetivo de reforçar a visão de Leonardo como um pensador universal, único em seu tempo e de espírito livre. Em outro texto, Koyré $\left(1973^{24}\right)$ se refere aos eventos comemorativos dos 500 anos do nascimento de Leonardo, nos quais estudiosos se esforçaram por oferecer uma melhor visão do papel de Leonardo na história do espírito humano. Koyré faz alusóes a visões exageradas e contraditórias: a visão de um homem que tudo leu e que foi lido por todos, contra a visão de um homem que nada leu e que não foi lido por ninguém. E, embora Koyré (1973, p. 107) sustente que o “[...] dilema entre 'rato de biblioteca' que repete o que leu ou puro gênio original que tudo cria ou inventa" seja um falso dilema, proveniente de "[...] uma projeção no passado das condiçóes preponderantes de nossos dias", podemos observar que

\footnotetext{
${ }^{22}$ Santillana (1953, p. 43), em sua comunicação Léonard et ceux qu'il n'a pás lus, faz uma referência clara a Sarton, quando afirma que Leonardo náo sofreu muito a influência do "preconceito platônico", comum aos artistas e geômetras de seu tempo.

${ }^{23}$ Elmer Belt (1952, p. 193), em sua comunicação sobre anatomia, indica pessoas que teriam tido acesso aos manuscritos de Leonardo, entre as quais estaria Huygens, em 1690.

24 "Texto inédito de uma conferência realizada em Madison (Wisconsin), em 1953" (KOYRÉ, 1973, p. 97). O texto apresenta passagens bastante semelhantes às de seu relatório final do Colóquio sobre Leonardo (KOYRÉ, 1953).
} 
ele não se mostra totalmente isento da dificuldade de se furtar dessa projeção. É o que podemos verificar na seguinte passagem:

O engenheiro Leonardo é certamente um dos maiores tecnólogos de todos os tempos. Mas o que dizer de Leonardo como físico? Os historiadores modernos, por uma reaçáo legítima contra os exageros dos seus predecessores, observaram que suas expressóes são frequentemente vagas e muitas vezes contraditórias; que sua tecnologia carece de precisão; que sua concepção de forza [...] é mítica ou poética [...] que sua noção de peso (gravidade), às vezes apresentada como uma causa e às vezes como efeito do movimento, é inconsistente. (KOYRÉ, p. 1973, p. 112).

Em outras passagens do texto, Koyré (1973, p. 113) afirma que a “[...] terminologia de Leonardo é, de fato, vaga e inconsistente"; que, “[...] apesar do seu atraso no domínio teórico, é muito interessante para um filósofo ou historiador da ciência estudar Leonardo como físico". Não obstante essas consideraçôes, podemos notar que a imagem que Koyré, como Sarton ${ }^{25}$, tem de Leonardo, é a de um gênio universal, singular e não suscetível à autoridade da tradiçẫo. Ele cita Vasari: "De tempos em tempos, o Céu nos envia alguém que não é somente humano, mas também divino, de modo que, por meio de seu espírito e da superioridade de sua inteligência, podemos atingir o Céu" (VASARI apud KOYRÉ, 1973, p. 99). A afirmação que abre o texto confirma a visão do historiador quanto ao reconhecimento de grandes gênios na ciência e revela sua predileçáo pela ciência moderna:

[...] graças a ele [Leonardo] e por meio dele, como temos visto, a técnica tornou-se tecnologia e o espírito humano elevou-se ao ideal de conhecimento no qual, um século mais tarde, se inspiraram Galileu e seus aliados, os membros da Accademia dei Lincei, que rejeitaram a autoridade e a tradição e que quiseram ver as coisas tal como eram. (KOYRÉ, 1973, p. 116).

As questôes que desfilam no colóquio de Paris também estão no texto de John Herman Randall Junior, originado da apresentação no simpósio em comemoração ao quinto centenário do nascimento de Leonardo, realizado em Nova Iorque, em 6 de dezembro de 1952 (RANDALL JR, 1953, p. 191, n. 1). Discutindo o conceito de ciência, Randall Junior se posiciona ao lado

\footnotetext{
${ }^{25}$ No texto "Leonardo da Vinci 500 anos depois", Koyré (1973, p. 108) cita Sarton somente uma vez - para lembrar que Leonardo foi muito mais um engenheiro do que um homem de ciência.
} 
de Sarton e Koyré, quando afirma que Leonardo desempenhou um papel significativo na tradição de inventores e não de cientistas.

As revisóes históricas motivadas pelas comemorações de 1952 continuaram ecoando no curso da história da ciência, e um bom exemplo disso é a introdução de Paolo Rossi ao volume que reúne os trabalhos expostos no Congresso internacional "Leonardo e a idade da razáo", ocorrido em Miláo, de 27 a 30 de setembro de $1982^{26}$. Para Rossi (1982, p. 1), “[...] a partir do centenário de 1952, [...] o modo de ler os fragmentos de Leonardo mudou notavelmente". Ele cita Dugas para falar do "[...] retrato, agora irremediavelmente distante, de Leonardo como um rat de bibliothèque repu de scolastique" e cita ainda Sarton e Koyré (ao lado de John Herman Randall Junior e Eugenio Garin) como responsáveis por uma "[...] polêmica eficaz contra os exageros de Duhem" (ROSSI, 1982, p. 1) ${ }^{27}$.

Rossi prioriza a investigação sobre a obra de Leonardo com foco sobre a tecnologia, rechaçando as infindáveis disputas sobre possíveis antecipações. A seu ver, náo faz sentido tratar de "ciência" nesse contexto histórico de investigação, uma vez que a ciência aparece para nós "[...] como um terreno dentro do qual a verdade se configura como algo que é submetido à prova da experiência, [...] à discussão e à competição contínua com teorias alternativas" (ROSSI, 1982, p. 2). E, assim, ele conclui que seria

[...] em vão procurar em Leonardo as linhas essenciais e constitutivas da nossa imagem moderna da ciência. É difícil não estar sempre de acordo com Randall, Sarton ou Koyré quando estes atestam que a pesquisa de Leonardo, cheia de intuiçôes brilhantes e visóes geniais, nunca ultrapassou

\footnotetext{
${ }^{26} \mathrm{O}$ volume Leonardo e l'età della ragione, que reúne os trabalhos expostos no evento, conta com duas dezenas de textos de estudiosos especialistas, os quais analisam os manuscritos de Leonardo em várias áreas. Sem espaço para discutir aqui as diversas questôes aí apresentadas, centramos nas discussōes de Rossi como um exemplo da retomada das constantes revisōes sobre o papel de Leonardo na história. Digna de nota, entretanto, é a afirmação (encontrada na descrição sintética do evento) de que Leonardo "[...] náo pode ser indicado o fundador da ciência moderna" (BELLONE; ROSSI, 1982, contracapa do livro e fôlder do evento).

${ }^{27}$ Vale lembrar que Garin defendeu a necessidade de se investigar a obra de Leonardo em consideração ao ambiente em que ele se formou. Duhem, a seu ver, mostra uma investigação com lacunas e prejudicada pela tentativa de supervalorizar a influência medieval (GARIN, 1996 [1965], p. 84). Mas, com Duhem, teria havido uma tentativa de finalmente situar Leonardo no seu ambiente histórico. Apesar dessa tentativa de Duhem (e a de Rafaello Caverni) de reavaliar a visão histórica do mito Leonardo, ainda permanecia "[...] a equívoca imagem de um Da Vinci 'homem sem letras', crítico ao mesmo tempo da Escolástica em nome do Renascimento, do humanismo filosófico em nome da ciência, do evasivo idealismo platônico florentino em nome da experiência" (GARIN, 1996, p. 8485). O texto de Sarton, apresentado no colóquio de 1951, é citado como exemplo dessa visão equívoca (GARIN, 1996, p. 103, n. 8).
} 
o plano dos experimentos 'curiosos', para atingir aquela sistematização que é característica fundamental da ciência e da técnica modernas [...] Leonardo náo tem interesse pela ciência como corpus organizado de conhecimentos nem concebe a ciência como empreendimento público e coletivo. (ROSSI, 1982, p. 3).

Esse ponto de vista de Rossi, que esclarece não fazer parte da comunidade de historiadores especialistas em Leonardo ${ }^{28}$, é encontrado em outros de seus textos. ${ }^{29}$ De modo geral, a exposição de Rossi retoma os argumentos de outros pensadores, para afirmar que Leonardo menosprezou a tipografia e a imprensa, que teve uma educação técnica dos ateliês do século XV, que teve postura revolucionária a que se liga "[...] a tese sobre a superioridade do olho sobre a mente, e da observação direta e minuciosa do mundo real sobre os livros e os textos" (ROSSI, 1989, p. 39). Rossi, Sarton e Koyré, em seus estudos sobre Leonardo, reforçam (ainda que de modo distinto ${ }^{30}$ ) a grande diferença entre a ciência medieval e a ciência moderna. E Leonardo deve ser visto unicamente como um homem da Renascença. Assevera Rossi (1982 p. 3): "Colocar Leonardo entre os fundadores da ciência significa colocar o seu retrato num lugar inapropriado da galeria”.

\section{As REVISÓES HISTÓRICAS DA OBRA DE LEONARDO E A NOVA HISTORIOGRAFIA DA CIÊNCIA}

Observando a história das revisôes acerca da contribuição científica de Leonardo, é possível detectar aspectos significativos das visôes históricas e historiográficas dos envolvidos nessas discussões quando analisamos a distinção entre uma historiografia mais antiga e a nova historiografia da ciência, tal como exposta por Thomas Kuhn.

Kuhn pouco menciona Leonardo da Vinci em seus escritos ${ }^{31}$, mas fez observaçóes sobre a obra de alguns dos historiadores que escreveram sobre o renascentista. Podemos, a partir da controvérsia sobre a contribuição científica de Leonardo, identificar alguns aspectos significativos da história e da historiografia da ciência ao longo de algumas décadas. O primeiro deles

\footnotetext{
${ }^{28}$ É o que ressalva Rossi (1982, p. 5).

${ }^{29}$ Ver, por exemplo, Rossi (1989, p. 37 e 2001, p. 74).

${ }^{30}$ Koyré e Rossi não partilham da visão negativa de Sarton acerca da Idade Média.

${ }^{31}$ Discutiremos as passagens em que isso ocorre mais adiante.
} 
diz respeito à descoberta da ciência medieval, fato considerado por Kuhn (1977, p. 108) como um dos acontecimentos decisivos para uma mudança significativa na história da ciência. Em texto em que discute o desenvolvimento desse campo, "A história da ciência”, Kuhn (1977, p. 122-123) cita os Études de Duhem na bibliografia, ao mesmo tempo em que indica as biografias de Sarton e Koyré como fonte para outros estudos relevantes. No referido texto, Kuhn afirma que

[...] a pesquisa de Pierre Duhem sobre as fontes da ciência moderna revelou uma tradição de pensamento da física medieval a que, em contraste com a física de Aristóteles, não se podia negar um papel essencial na transformação da teoria física que ocorre no século XVII. Muitos dos elementos da física e do método de Galileu deviam ser encontrados aí. Mas não era possível assimilá-la completamente à física de Galileu nem à de Newton, o que deixaria a estrutura da chamada Revolução Científica imutável, mas bastante estendida no tempo [...] Mais do que qualquer outra, essa mudança tem moldado a moderna historiografia da ciência. Os escritos que ela tem suscitado desde 1920, particularmente aqueles de E.J. Dijksterhuis, Annelise Maier e, especialmente, Alexandre Koyré, são os modelos que muitos contemporâneos visam emular. (KUHN, p. 1977, p. 108).

Na sequência, Kuhn ressalta ainda o fato de que a descoberta da ciência medieval e do papel desta, na Renascença, revelou "[...] uma área na qual a história da ciência pode e deve ser integrada com outros tipos de histórias mais tradicionais". Ele cita como exemplos de trabalhos, nesse sentido, a “[...] síntese pioneira de Butterfield" e "[...] estudos especiais de Panofsky ${ }^{32}$ e Frances Yates”.

Sarton, segundo Kuhn, está relacionado a outro fator determinante na formulação da nova historiografia, na medida em que pôs em prática, em sua obra monumental, a tentativa de elaborar uma história da ciência geral. Ainda que reconheça a dificuldade de se escrever uma história da evoluçáo da ciência de modo global, Kuhn assinala que a tentativa foi "[...] crucial porque acentuou a impossibilidade de atribuir, ao passado, as divisôes incorporadas nos currículos da ciência contemporânea" (KUHN, 1977, p. 109).

Embora Duhem, Sarton e Koyré apareçam como nomes importantes na análise dos fatores que determinaram mudanças para uma nova historiografia,

32 É interessante observar que Panofsky, em seu texto de 1953, "Artist, Scientist, Genius: Notes on the Renaissance-Dämmerung" (1953), já menciona alguns dos trabalhos apresentados no Colóquio de 1952, realizado em Paris. 
eles não continuam no mesmo grupo quando Kuhn estabelece uma distinção entre tradiçóes historiográficas a serem superadas e uma nova, a qual surgia promissora. O nome de Koyré aparece já em A estrutura das revoluçôes cientificas como pertencente a um novo movimento que mostrava a Kuhn - ele o afirma - o que poderia ser a história da ciência ${ }^{33}$ e, depois disso, é mencionado em vários outros de seus escritos, de modo geral, com grandes elogios, e, em um deles, sob o título de maitre $e^{34}$. Koyré, para Kuhn, era um dos responsáveis pela revolução historiográfica em curso nos anos 1960.

Ainda de acordo com Kuhn, foi durante essa revolução que, ao invés de procurarem, como seus antecessores, as contribuiçóes de uma ciência mais antiga para a perspectiva privilegiada de seu momento presente, alguns historiadores buscavam fazer uma narrativa de modo a preservar a integridade histórica do contexto investigado. Assim, no lugar de pesquisarem as relaçóes entre as concepçôes de Galileu e a ciência moderna, deveriam investigar as relaçóes entre as concepçôes galileanas e as de seu grupo (seus professores, contemporâneos e sucessores imediatos), com atenção para os pontos de vista próprios do contexto desse grupo (KUHN, 1970b, p. 3). Em "Leonardo da Vinci 500 anos depois”, Koyré (1973, p. 100) faz essa consideração quanto ao próprio Leonardo: "A fim de situá-lo exatamente, temos de confrontá-lo com seus predecessores, seus contemporâneos e seus sucessores".

Já Sarton aparece, na visão de Kuhn, como um típico historiador pertencente às mais velhas histórias da ciência, a uma tradição que concebia "[...] o avanço científico como o triunfo da razão sobre a superstição primitiva, o único exemplo da humanidade operando em seu modo mais elevado." (KUHN, 1977, p. 148). De fato, quando analisamos os escritos de Sarton sobre Leonardo, um dos aspectos mais significativos é justamente sua ênfase na imagem de "[...] um defensor da razão, um inimigo da superstição." (SARTON, 1957, p. 233).

$\mathrm{Na}$ longa entrevista de $1995^{35}$, publicada em $O$ caminho desde $A$ estrutura, Kuhn (2000, p. 282) se refere a Sarton como um historiador $\mathrm{Whig}^{36}$,

\footnotetext{
${ }^{33} \mathrm{O}$ nome de Koyré acompanha os de Émile Meyerson, Hélène Metzger e Anneliese Maier (KUHN, 1970 b, p. vi).

${ }^{34}$ É o que se lê em Kuhn (1977, p. 21).

35 "A discussion with Thomas S. Kuhn" (KUHN, 2000).

${ }^{36} \mathrm{O}$ adjetivo whig foi introduzido por Herbert Butterfield, em The Whig Interpretation of History (1965 [1931]), para designar a atitude dos historiadores que investigam o passado a partir de um ponto de vista determinado por valores e padrōes de seu momento presente.
} 
que via a ciência como o modelo para todas as coisas e como alguém que poderia the ter fornecido uma porção de dados, mas que não significavam, para ele, verdadeiramente história. Quanto a Koyré, na mesma entrevista, ele afirma ter amado Etudes Galiléennes (KUHN, 2000, p. 285), que the mostravam um jeito promissor de se fazer história da ciência.

Em outra entrevista, também de 1995, publicada pelo Le monde, quando indagado acerca de quais autores teriam desempenhado um papel na formaçáo de seu pensamento, depois de mencionar os costumeiros nomes de Alexandre Koyré, Arthur Lovejoy, Emile Meyerson, Hélène Metzger ${ }^{37}$, Kuhn afirma: "Quanto a Duhem, mantive dele principalmente a ideia de que, para se compreender a passagem da física antiga à física moderna, não se pode fazer economia da física medieval." (KUHN apud OLIVEIRA, 2012, p. 232).

Vale lembrar que Sarton também esteve empenhado em escrever a história da ciência da Idade Média e é citado, ao lado de Duhem, nas notas bibliográficas do livro de Kuhn, The Copernican Revolution (1970a). Contudo, temos de reconhecer a distância que separa as visóes de Duhem e Sarton sobre a maneira como retratam o contributo dos medievais. Enquanto a visão de Duhem é engrandecedora desse legado, a de Sarton é bastante depreciativa. Quanto a isso, Kuhn está inegavelmente ao lado de Duhem. A seção "os críticos escolásticos de Aristóteles" do capítulo 4 do livro de Kuhn reflete bem isso. Nas mesmas notas bibliográficas, Kuhn (1970a, p. 283) ressalta que “[...] todas as histórias gerais da ciência discutem o período" [discutido no livro], mas que "somente Herbert Butterfield, The Origins of Modern Science [...] teve uma influência particular na estrutura” do livro. Na discussão de Butterfield sobre as origens da ciência moderna, encontramos uma passagem significativa referente à escolástica e a Leonardo, a qual corrobora a análise duhemiana:

[...] pelo menos, desde o início do século XX, tem crescido o interesse por essa escola de pensadores que, já no distante século XIV, questionaram as explicaçôes aristotélicas do movimento e apresentaram uma doutrina alternativa do impetus que, embora imperfeita, representa o primeiro estágio na história da revolução científica. [...] [Esta escola] tem uma história contínua: sabemos como esse ensino chegou à Itália, como foi promulgado nas universidades da Renascença e como Leonardo da Vinci o assumiu, de tal modo que, alguns aspectos, que uma vez foram considerados rompantes notáveis de modernidade, flashes extraordinários de gênio em seus cadernos de nota, eram, na realidade, transcriçóes dos autores escolásticos parisienses do século XIV. (BUTTERFIELD, 1966, p. 20).

${ }^{37}$ Ver, por exemplo, Kuhn (1970b, p. vi; 2000, p. 285-287). 
Talvez a maior relutância contra a visão duhemiana se deva justamente à substituição da imagem de Leonardo como milagre, como um gênio isolado e dotado de insights, pela de um homem que também sofreu influências - a mudança a que alude Butterfield ${ }^{38}$. Sarton, Koyré e Rossi não compartilharam inteiramente da visão duhemiana e esforçaram-se por refutar a suposta diminuiçẫo da grandeza do gênio renascentista e exaltar sua originalidade na investigação da natureza, sua atitude revolucionária: ao invés de se voltar para os livros, Leonardo se voltou para a observação do mundo real. Essa repetida perspectiva que contrapóe a ciência medieval à moderna é alvo da crítica de Kuhn, quando argumenta:

Alguns historiadores sustentaram que a própria ideia de basear a ciência em informação adquirida através dos sentidos era nova. Aristóteles, de acordo com essa visão, acreditava que as conclusốes científicas poderiam ser deduzidas de primeiros princípios axiomáticos; até o fim do Renascimento, os homens náo conseguiram se libertar de sua autoridade suficientemente para estudar a natureza em vez dos livros. Estes resíduos da retórica do século XVII são, contudo, absurdos. (KUHN, 1977, p. 41).

Como vimos, Sarton, Koyré e Rossi mantêm, em graus distintos, "resíduos da retórica do século XVII" quando analisam a atitude moderna de Leonardo de investigar a natureza e não os livros. É no texto do qual a citação acima é extraída, "Tradição matemática versus tradição experimental no desenvolvimento da ciência física”, que Kuhn menciona Leonardo da Vinci três vezes, como exemplo para discutir problemas de interpretação na análise histórica dessas tradiçóes ${ }^{39}$. Assevera Kuhn (1977, p. 49): “[...] como indica também a carreira de Leonardo, as preocupaçóes instrumentais ou de engenharia não fazem de um homem um experimentalista”. Em outra passagem, Leonardo e Brunelleschi são mencionados como exemplos de artistas-engenheiros com diversas habilidades, as quais contribuíram para fomentar o novo saber erudito, na medida em que compreenderam e comentaram obras clássicas como De architetura, de Vitrúvio, a Geometria e a Óptica, de Euclides (KUHN, 1977, p. 55). Leonardo serve ainda de exemplo

\footnotetext{
${ }^{38}$ Se é verdade que Duhem exagerou em suas análises, não é menos verdade que seus opositores também exageraram quando imputaram a ele a imagem de "um rato de biblioteca". Como já argumentamos em outro trabalho (OLIVEIRA, 2012), os Études trazem muitos elementos que corroboram a caracterização da singularidade e da genialidade de Leonardo, semelhantes inclusive àqueles que encontramos nos escritos daqueles que o retrataram como um gênio isolado.

${ }^{39}$ Em A estrutura das revoluçôes científicas, Kuhn (1970b, p. 161) cita Leonardo como exemplo dos homens que, na Renascença, não estabeleciam uma separação entre as ciências e as artes.
} 
a Kuhn para argumentação de que o utilitarismo foi um aspecto central somente nas ciências baconianas:

\begin{abstract}
Embora os artistas-engenheiros da Renascença fossem úteis socialmente, soubessem e, por vezes, baseassem nisso suas pretensóes, os elementos utilitários em seus escritos eram muito menos persistentes e estridentes do que os presentes nos escritos daqueles que estabeleceram os ofícios não mecânicos. Lembremo-nos de quão pouco Leonardo se preocupava se os dispositivos mecânicos que inventava poderiam ser construídos realmente. (KUHN, 1977, p. 57-58).
\end{abstract}

As mençôes de Leonardo no texto de Kuhn têm a função de atentar para uma maneira diferente de abordar a tradiçẫo das ciências clássicas e a das ciências baconianas. Leonardo, invariavelmente, aparece inserido na tradição da ciência clássica. Assim, a suposta antecipação de Leonardo do método baconiano (tal como afirmado por Sarton) e o destaque do caráter pragmático da obra de Leonardo (tal como colocado por Koyré) são questionados no texto kuhniano. Ainda em 1976, Kuhn insiste na necessidade de aprimorar a história da ciência, nas análises sobre o início da ciência moderna e na identificação de fatores significativos para a emergência da revolução científica.

\title{
CONSIDERAÇóEs FINAIS
}

A longa controvérsia sobre a obra científica de Leonardo da Vinci não abalou o estatuto de sua grandeza e o sentimento de fascínio por sua obra. Não é sem razão que Paolo Rossi, após discutir as revisôes históricas acerca dos manuscritos e reclamar que "[...] suas fontes devem ser individualizadas e sua gênese esclarecida”, afirma que a leitura de seus fragmentos e a análise se seus desenhos "[...] continuam a deixar em cada um de nós [...] aquele mesmo tipo de perturbação" (ROSSI, 1982, p. 5). Exaltada de modo diferente por historiadores, essa perturbação tem sido trabalhada e discutida dentro de contextos cronológicos com fins específicos, os quais modificaram substancialmente e gradativamente a história e a historiografia da ciência.

Para Pierre Duhem, os manuscritos são uma fonte que atesta um legado de uma tradição que, por séculos, foi julgada inexistente. A descoberta de contribuiçóes significativas dos medievais como fomentadora de mudanças que se efetivariam na revoluçáo científica alterou a narrativa histórica do 
desenvolvimento científico. Como ressalta Harcourt Brown, a história da ciência

[...] é o produto de historiadores; suas categorias permanecem fluídas enquanto novas perspectivas e ênfases produzem novas avaliaçóes. [...] Quando o trabalho de Pierre Duhem, por exemplo, progrediu e foi absorvido, a perspectiva mudou e muito da ciência do século XVI perdeu seu fascínio. (BROWN, 1960, p. 42).

A análise de Brown foca a mudança de visão em relação à Renascença, mas pode, por extensão, ser aplicada à revolução científica. Se é verdade que a visão duhemiana vai contra a concepção da Renascença como um período de surgimento de produtividades esparsas (fulgurais e geniais) após as trevas da Idade Média, para muitos historiadores, ela também diminuía o mérito dos cientistas do século XVII e, portanto, reduzia a grandeza - e, em algumas interpretações, até mesmo a plausibilidade de se falar - da revolução científica.

Vimos que Sarton reconhece a necessidade de se estudar a ciência medieval, mas mantém aspectos da visão depreciativa da Idade Média, sobretudo no que toca à avaliação da escolástica. Koyré, que, como Sarton, não recusa a continuidade da ciência, enfatiza a distância que existe entre a ciência medieval e a ciência moderna, sugerindo que a admissão do continuísmo, tal como defendido por Duhem, implica necessariamente a negação da existência da revolução científica ${ }^{40}$. Ao lado de Sarton e Koyré, Rossi alude à atitude revolucionária de Leonardo que se volta para a investigaçáo da natureza ao invés dos livros.

Aliás, a disputa entre a afirmação de que Leonardo leu e de que Leonardo náo leu pode, à primeira vista, parecer frívola. Contudo, a nosso ver, ela fornece indícios do foco de atenção dos historiadores nas constantes escritas e reescritas do passado do empreendimento científico. Em Sarton, reflete a relutância em aceitar que a ciência da Idade Média tenha sido, de fato, muito produtiva para a ciência moderna; que o escolasticismo tenha sido um movimento profícuo, enfim, implicaria a rejeição de uma visão fortemente estabelecida e consagrada em seu tempo que caracterizava a ciência moderna como a superação do preconceito e da autoridade. Para Koyré, a aceitação de Leonardo como leitor (tal como exposto por Duhem) acarretaria a aceitação de que a Idade Moderna foi uma mera continuação da Idade Média, o que diminuiria o "fosso" entre a

${ }^{40}$ Oliveira (2012) discute essa interpretação, analisando diversas obras de Duhem. 
ciência moderna e a medieval e, consequentemente, a grandeza da revolução científica. E, por fim, para Rossi, a recusa de Leonardo como um homem que muito leu revela a sua crença de que a técnica renascentista e não a erudição tenha tido resultados avassaladores no século XVII.

Admitidas as diferenças quanto à manutenção de "resíduos da retórica do século XVII", presentes na obra de historiadores da ciência contemporâneos de Kuhn, podemos verificar que esses resíduos somente se tornaram absurdos em função das constantes revisões históricas. É assim que podemos ler Sarton, Koyré ou Rossi tratando da visão ultrapassada da Idade Média como idade das trevas ${ }^{41}$.

De modo geral, a análise histórica da obra de Leonardo aparece ligada a uma finalidade: para Duhem, o da reavaliação da Idade Média; em Sarton, para promulgar a história da ciência "[...] como o triunfo da razão sobre a superstição" "22; em Koyré, para reavaliação da revolução científica após o reconhecimento da importância dos medievais; para Rossi, na análise do papel dos engenheiros da Renascença em sua história da ciência, com ênfase na técnica e na tecnologia. A reação dos últimos contra a visão de Duhem pode ser compreendida, se nos voltarmos para o exame dos momentos distintos da história da ciência em que escreveram. Lembramos, por exemplo, de Kuhn quando situa a obra de Koyré no período da revolução historiográfica ainda em curso. Apesar de considerá-lo um historiador mestre, Kuhn náo se absteve de identificar características a serem superadas em sua história da ciência. Afinal, na revolução em curso, a história se alterava gradativamente e muita coisa ainda estava por se fazer. É nesse sentido que, em "Tradição matemática versus tradição experimental na ciência física”, Kuhn se esforça por mostrar a necessidade de um novo prisma para se analisar a questio disputata, a que se refere Crombie (1969, p. 80).

Finalmente, podemos evocar a afirmação kuhniana na introdução de sua obra de 1962: a de que poderíamos extrair da história uma nova imagem de "ciência", mas que essa nova imagem deveria ser oriunda de uma história nova. A literatura histórica da obra científica de Leonardo pode servir como mote para exemplificar quão polêmicas podem se mostrar as

\footnotetext{
${ }^{41}$ Rossi (1989, p. 40) é taxativo com relação a isso: "Não há dúvidas de que as imagens tradicionais da noite medieval e de um Renascimento que vitoriosamente dissipa para sempre suas trevas estão agora definitivamente ultrapassadas". A afirmação de Rossi ocorre em passagem que ressalta a "[...] profunda distância que separa a ciência medieval da ciência moderna”, sobretudo na análise da história da técnica.

${ }^{42}$ Para Sarton (1930, p. xvii), a história da ciência deve ser tomada como cerne da história da cultura e esta "[...] é essencialmente a história de uma luta gigantesca entre luz e escuridão, entre conhecimento e ignorância”.
} 
revisóes por periodizaçóes do desenvolvimento da ciência e mais que isso: tem-se mostrado um campo fértil para a discussáo do próprio conceito de ciência. $\mathrm{Na}$ análise dos historiadores que se empenharam em revisar o papel de Leonardo no desenvolvimento da ciência, muito aprendemos sobre o papel que esses historiadores tiveram na história da ciência. Se o projeto de uma enciclopédia leonardesca se tornou inexequível, os estudos existentes podem não só evidenciar por que Leonardo da Vinci tem sido invariavelmente objeto de fascínio, mas podem também revelar muito sobre o que tem sido a história e a historiografia da ciência.

OLIVEIRA, Amélia de Jesus. The scientific work of Leonardo da Vinci: controversies in the historiography of Science. Trans/form/ação, Marília, v. 39, n. 2, p. 53-86, Abr./Jun., 2016.

\begin{abstract}
Interpreters of Leonardo da Vinci's manuscripts share the same feelings of astonishment and fascination when they examine his contribution to modern science. However, it is possible to perceive an ongoing attempt towards a historical revision of the role played by Leonardo. Observing the history of this ongoing revision, it is possible to detect significant aspects of the historical and historiographical perspectives of those involved in this discussion. This article deals with the controversy between Duhem's point of view, on the one hand, and the views of Sarton, Koyré, and Rossi on the other. It aims to show some features that distinguish an older historiography from the new historiography of science as presented by Thomas Kuhn.
\end{abstract}

KEYWORDS: Leonardo da Vinci, modern science, Renaissance, continuity.

\title{
REFERÊNCIAS
}

BELLONE, E.; ROSSI, P. (Ed.). Leonardo el'età della ragione. Milano: Scientia, 1982.

BELT, E. Les dissections anatomiques de Léonard de Vinci. In: FEBVRE, L. et al. Léonard de Vinci \& l'expérience scientifique au seizième siècle. Paris: Presses Universitaires de France, 1953. p. 189-224.

BROWN, H. The renaissance and historians of science. Studies in the Renaissance, v. 7, p. 27- 42, 1960.

BURCKHARDT, J. A cultura do Renascimento na Itália: um ensaio. Tradução de Sérgio Tellaroli. São Paulo: Companhia das Letras, 1991.

BUTTERFIELD. H. The Whig interpretation of history. New York: W. W. Norton \& Company, 1965. 
. The origins of modern science 1300-1800. New York: The Free Press, 1966.

CLAGETT, M. (Org.). Critical problems in the history of science. Madison: University of Wisconsin Press, 1969.

COHEN, B. I. Alexandre Koyré in America: some personal reminiscences. History and Technology, London: Harwood Academic, v. 4, n. 1/4, p. 55-70, 1987. (Spessial Issue: Science: the renaissance of a history Editado por P. REDONDI. In: PROCEEDINGS OF THE INTERNATIONAL CONFERENCE, Paris, June 1986).

. Revolution in science. Cambridge: Harvard University Press, 1994.

CROMBIE, A. C. The Significance of medieval discussions of scientific method for the scientific revolution. In: CLAGETT, M. (Org.). Critical problems in the history of science. Madison: University of Wisconsin Press, 1969. p. 66-78.

DUGAS, R. Léonard de Vinci dans l'histoire de la mécanique. In: FEBVRE, L. et al. Léonard de Vinci \& l'expérience scientifique au seizième siècle. Paris: Presses Universitaires de France, 1953. p. 89-114.

DUHEM, P. M. M. Études sur Léonard de Vinci: ceux qu'il a lus et ceux qui l'ont lu. Paris: Archives Contemporaines, 1984. 3 V.

FEBVRE, L. et al. Léonard de Vinci \& l'expérience scientifique au seizième siècle. Paris: Presses Universitaires de France, 1953.

FERGUSON, W. K. La renaissance dans la pensée historique. Tradução de Jacques Marty. Paris: Payot, 1950.

GARIN, E. Ciência e vida civil no Renascimento italiano. Tradução de Cecília Prada. São Paulo: Editora da UNESP, 1996.

KOYRÉ, A. Rapport final. In: FEBVRE, L. et al. Léonard de Vinci \& l'expérience scientifique au seizième siècle. Paris: Presses Universitaires de France,1953. p. 237-246.

. Études d'histoire de la pensée scientifique. Paris: Gallimard, 1973.

KUHN, T. S. The Copernican revolution: planetary astronomy in the development of Western Thought. Cambridge: Harvard University Press, 1970a.

. The structure of scientific revolutions, Chicago: University of Chicago Press, $1970 \mathrm{~b}$.

. The essential tension. Chicago: The University of Chicago Press, 1977.

. The road since structure. Chicago: The University of Chicago Press, 2000.

LIBRI, G. Histoire des Sciences mathématiques en Italie. Paris: J. Renouard, 1840. Disponível em:<www.archive.org/details/histoiredesscien03libr>. Acesso em: 26 nov. 2014.

MAIOCCHI, R. Chimica e filosofia: scienza, epistemologia, storia e religione nell'opera di Pierre Duhem. Firenze: La Nouva Itália, 1985. 
MARTIN, R. N. D. Pierre Duhem: philosophy and history in the work of a Believing physicist. La Salle, Illinois: Open Court, 1991.

OLIVEIRA, A. J. Duhem e Kuhn: continuísmo e descontinuísmo na história da ciência. 2012. 258 f. Tese (Doutorado em Filoasofia) - Instituto de Filosofia e Ciências Humanas, Universidade Estadual de Campinas, Campinas, SP, 2012.

PANOFSKY, E. Artist, scientist, genius: notes on the Renaissance-Dämmerung. In: FERGUNSON, W. et al. The Renaissance. New York: Harper Torchbooks, 1963. p.121-182.

PINTO DE OLIVEIRA, J. C.; OLIVEIRA, A. J. Kuhn, Sarton, and the history of science. In: PISANO, R. et al. (Ed.). Hypotheses and perspectives within history and philosophy of science. Hommage to Alexandre Koyré, 1964-2014. Dordrecht: Springer (no prelo).

PRESTON, J. Kuhn's the structure of scientific revolutions: a reader's guide. London: Continuum, 2008.

RANDALL JR., J. H. The place of Leonardo Da Vinci in the emergence of modern science. Journal of the History of Ideas, v. 14, n. 2, p. 191-202, 1953.

ROSENTHAL, E. Changing interpretations of the Renaissance in the history of art. In: HELTON, T. (Ed.). The Renaissance. a reconsideration of the theories and interpretations of the age. Madison: The University of Wisconsin Press, 1964. p. 53-75.

ROSSI, P. Introduzione. In: BELLONE, E. ; ROSSI, P. (Ed.). Leonardo el étà della ragione. Milano: Scientia, 1982. p. 1-5.

. Os filósofos e as máquinas. Tradução de Federico Carotti. São Paulo: Companhia das Letras, 1989.

. O nascimento da ciência moderna na Europa. Tradução de Antonio Angonese. Bauru: EDUSC, 2001.

RUPERT HALL, A. The Scholar and the Craftsman in the scientific revolution. In: CLAGETT, M. (Org.). Critical problems in the history of science. Madison: University of Wisconsin Press, 1969. p. 3-23.

SANTILLANA, G. Léonard et ceux qu'il n'a pas lus. In: FEBVRE, L. et al. Léonard de Vinci \& l'expérience scientifique au seizième siècle. Paris: Presses Universitaires de France, 1953. p. 43-59.

SARTON, G. Une encyclopédie léonardesque. Raccolta Vinciana, v. 10, p. 235-242, 1919. . Introduction to the history of science. Baltimore: Williams and Wilkins, 1927. V. 1. . Preface. In: McMURRICH, J. P. Leonardo da Vinci, the Anatomist (1452-1519). Baltimore: The Williams \& Wilkins, 1930. p. xv-xx. 1948. . The life of science: essays in the history of civilization. New York: Henry Schuman, . Leonardo da Vinci. Miniatures. The metropolitan museum of art. Album LL, 1952. 
. Intervention de M. Sarton après la communication de M. Dugas. In: FEBVRE, L. et al. Léonard de Vinci \& l'expérience scientifique au seizième siècle. Paris: Presses Universitaires de France, 1953a. p. 114.

. Intervention de M. Sarton après la communication de M. Koyré. In: FEBVRE, L. et al. Léonard de Vinci \& l'expérience scientifique au seizième siècle. Paris: Presses Universitaires de France, 1953b. p. 246.

. Léonard de Vinci ingénieur et savant. In: FEBVRE, L. et al. Léonard de Vinci \& l'expérience scientifique au seizième siècle. Paris: Presses Universitaires de France, 1953c, p. 11-22.

Sixth Wing Leonardo da Vinci: Art and Science. In: SARTON, G. Six Wings: men of science in the Renaissance. Bloomington, Indiana: Indiana University Press, 1957. p. 219-233.

Science in the Renaissance. In: THOMPSON, J. W. et al. The civilization of the Renaissance. New York: Frederick Ungar, 1959 [1929]. p. 75-95.

. Sarton on the history of science: essays by George Sarton. Editado por Dorothy Stimson. Cambridge, Massachusetts: Harvard University Press, 1962.

SERGESCU, P. Léonard de Vinci et les mathématiques. In: FEBVRE, L. et al. Léonard de Vinci \& l'expérience scientifique au seizième siècle. Paris: Presses Universitaires de France, 1953. p. 73-88.

STIMSON, D. Preface. In: SARTON, G. Sarton on the history of science: essays by George Sarton. Editado por Dorothy Stimson. Cambridge, Massachusetts: Harvard University Press, 1962. p. v-x.

THAYER, W. R. Leonardo da Vinci as a Pioneer in Science. The Monist, v. 4, p. 507-532, 1894. Disponível em: <https://archive.org/details/jstor-27897179>. Acesso em: 10 dez. 2014.

VASARI, G. Le vite de’più eccellenti pittori, scultori e architettori. Firenze, 1771. Disponível em: <http://www.archive.org/details/vitedepieccell003vasa>. Acesso em: 18 maio 2014.

Recebido em 04/11/2015

Aceito em 29/02/2016 